\title{
Deskripsi Keterampilan Proses Sains Peserta Didik Kelas XI IPA pada Materi Larutan Penyangga di SMAN 15 Padang
}

\author{
Selvi Desideria, Latisma Dj, Rahadian Zainul \\ Jurusan Kimia, FMIPA Universitas Negeri Padang, Indonesia \\ Email : latismadj@gmail.com
}

\begin{abstract}
Scientific process skills are skills that emphasize the learning, activities, and creativity of students to gain knowledge. Skills of the science process are classified into the psychomotor domain whose judgment tends to be neglected or not yet done optimally. The purpose of this research was to describe the science process skill of students class XI IPA on buffer solution material. The type of this research was descriptive research conducted at SMAN 15 Padang. The sample of research was grade XI IPA 5 and XI IPA 6. Instrument in this research was observation sheet to see the level of emergence of science process skill classified in three levels that was: exist and accordingly, exist but not appropriate, and not yet exist. Skills of the process of science seen from the activities of learning in the classroom and practical work that emergence has not developed optimally. Based on the results of data analysis, KPS indicators were existing and appropriate categories of skills that formulate hypotheses and using tools/materials. The KPS indicators in the category existed but were not appropriate is the skills of observing, interpreting, and applying concepts. Furthermore, the KPS indicators wich were not yet come were ask question and communication skills.

Keyword - science process skills, buffer solution
\end{abstract}

\section{PENDAHULUAN}

Ilmu Pengetahuan Alam (IPA) merupakan salah satu cabang pokok ilmu pengetahuan yang di dalamnya terdapat berbagai cabang ilmu diantaranya, ilmu biologi, fisika, dan kimia. Masing-masing cabang ilmu tersebut memiliki karakteristik yang berbeda-beda yang membedakan dengan cabang ilmu lainnya. Perkembangan ilmu pengetahuan yang semakin lama semakin canggih menghasilkan banyaknya konsep-konsep yang harus dipelajari peserta didik dalam pembelajaran. Oleh karena itu, seorang guru harus mempunyai cara agar semua konsep-konsep dapat tersampaikan dengan baik kepada peserta didiknya[11-16].

Ilmu kimia merupakan kumpulan dari pengetahuan fakta, konsep, prinsip, hukum, dan teoriteori. Untuk menemukan fakta, konsep, prinsip, hukum dan teori dalam pembelajaran kimia, maka diperlukan aktivitas-aktivitas peserta didik yang terkait dengan sains yang disebut keterampilan proses sains.

Pendekatan keterampilan proses merupakan pendekatan pembelajaran yang menekankan pada proses belajar, aktivitas dan kreativitas peserta didik dalam memperoleh pengetahuan, keterampilan, nilai dan sikap, serta menerapkannya dalam kehidupan sehari-hari ${ }^{[1]}$. Keterampilan proses sains peserta didik dapat dilihat dalam kegiatan pembelajaran di kelas dan kegiatan praktikum. Untuk mengembangkan keterampilan proses tersebut, maka seorang guru harus mampu menyampaikan materi dengan merancang pembelajaran yang efektif, membuat instrumen yang diperlukan, dan melakukan evaluasi terhadap apa yang telah diajarkan. Pengembangan keterampilan proses sains menjadikan siswa secara mandiri mengkontruksi pengetahuannya dan memberi makna melalui pengalaman nyata untuk menemukan fakta-fakta, membangun konsep, teori dan sikap ilmiah[11-16].

Indikator keterampilan proses sains yaitu: keterampilan mengamati (observasi), mengelompokkan (klasifikasi), menafsirkan (interpretasi), meramalkan (prediksi), mengajukan pertanyaan, merumuskan hipotesis, merencanakan percobaan, menggunakan alat/bahan, menerapkan konsep, dan berkomunikasi[2].Dengan mengembangkan keterampilan-keterampilan proses sains, 
maka peserta didik akan mampu menemukan dan mengembangkan sendiri fakta dan konsep, serta mampu mengembangkan sikap dan nilai yang dituntut. Oleh karena itu, keterampilan proses sains merupakan roda penggerak penemuan dan pengembangan fakta dan konsep, serta pengembangan sikap dan nilai yang dituntut, yang akan menciptakan kondisi belajar peserta didik yang aktif.

Keterampilan proses sains termasuk dalam ranah psikomotorik. Ranah psikomotorik merupakan ranah yang berkaitan dengan keterampilan atau kemampuan bertindak setelah seseorang menerima pengalaman belajar tertentu[3]. Dalam pembelajaran kimia, penilaian aspek psikomotorik dilihat dari kemunculan keterampilan-keterampilan proses sains dari peserta didik selama kegiatan pembelajaran di kelas dan kegiatan praktikum.

Kenyataan yang umum terjadi saat ini, pengukuran hasil belajar oleh para guru pada proses pembelajaran hanya terfokus pada aspek kognitif. Guru hanya berupaya bagaimana peserta didiknya dapat menjawab soal-soal yang diberikan dalam ujian dan mendapatkan perolehan nilai di atas standar yang ditetapkan, namun cenderung melupakan bagaimana untuk mengembangkan dan mengaplikasikan keterampilan (skill) dari peserta didik setelah mendapatkan pengalaman belajar tertentu. Hal ini berdampak pada banyaknya hasil belajar peserta didik yang rendah, dikarenakan mereka cenderung hanya menghafal konsep-konsep yang telah diberikan, namun tidak mampu memahami dan memaknainya melalui pengamatan dan pengalamannya. Hasil belajar psikomotor sebenarnya merupakan kelanjutan dari hasil belajar kognitif (memahami sesuatu) dan hasil belajar afektif (kecenderungan untuk berprilaku).

Berdasarkan hasil wawancara penulis dengan salah seorang guru kimia kelas XI di SMA Negeri 15 Padang dan observasi yang telah dilakukan, dapat diketahui bahwa keterampilan proses sains peserta didik belum berkembang secara optimal di sekolah tersebut. Hal ini disebabkan karena penilaian pada ranah psikomotorik cenderung terabaikan. Penilaian lebih diutamakan pada ranah kognitif, sedangkan penilaian aspek psikomotorik cenderung mengikuti hasil dari penilaian pada ranah kognitif. Hal ini berdampak pada kemunculan keterampilan-keterampilan proses sains peserta didik yang sangat sedikit dalam kegiatan pembelajaran, terutama pada kegiatan praktikum. Peserta didik menganggap aktivitas selama praktikum yang mereka lakukan tidak begitu ternilai, karena hasil utama dilihat dari nilai ulangan/ujian menggunakan tes tertulis. Salah satu materi pelajaran kimia SMA yang kemunculan keterampilan proses sains sangat sedikit dalam aktivitas pembelajaran di kelas dan kegiatan praktikum adalah materi Larutan Penyangga (Buffer).

Berdasarkan latar belakang di atas, maka penulis melakukan penelitian dengan mengambil judul "Deskripsi Keterampilan Proses Sains Peserta Didik Kelas XI IPA pada materi Larutan Penyangga di SMA Negeri 15 Padang".

\section{METODE PENELITIAN}

Jenis penelitian ini adalah peneltian deskriptif. Penelitian deskriptif adalah penelitian yang digunakan untuk mendeskripsikan dan menjawab persoalan-persoalan terhadap fenomena yang terjadi saat ini, baik itu fenomena dalam variabel tunggal atau korelasi serta perbandingan berbagai variabel[4].

Populasi dalam penelitian ini adalah seluruh siswa kelas XI IPA di SMAN 15 Padang. Populasi adalah keseluruhan subjek penelitian[5]. Kelas yang terpilih menjadi sampel adalah kelas XI IPA 5 dan XI IPA 6. Teknik pengambilan sampel yaitu Cluster Random Sampling. Instrumen penelitian yaitu lembar observasi untuk mengukur tingkat kemunculan keterampilan proses sains peserta didik. Instrumen penelitian merupakan suatu alat yang digunakan untuk mengukur fenomena yang diamati, baik itu fenomena alam maupun sosial[6].

Teknik pengumpulan data dalam penelitian ini didapatkan dari data lembar observasi. Peneliti melakukan observasi selama kegiatan pembelajaran di kelas dan pelaksanaan kegiatan praktikum untuk melihat kemunculan keterampilan proses sains peserta didik. Langkah-langkah dalam teknik analisis data yaitu: memberikan tingkatan dari setiap sub aspek keterampilan proses sains hasil observasi (ada dan sesuai (3), ada tetapi tidak sesuai (2), dan belum ada (1)), menghitung jumlah peserta didik yang tergolong pada masing-masing tingkatan, menentukan persentase masing-masing kategori pada tiap-tiap indikator, dan menginterpretasikan secara deskriptif persentase tiap aspek keterampilan proses sains siswa yang muncul selama kegiatan pembelajaran di kelas dan kegiatan praktikum. 


\section{HASIL DAN PEMBAHASAN}

\subsection{Deskripsi Data}

Penelitian ini dilakukan di SMA Negeri 15 Padang yang bertujuan untuk memperoleh data mengenai keterampilan proses sains peserta didik kelas XI IPA pada materi Larutan Penyangga. Sampel yang terpilih adalah kelas XI IPA 5 dan XI IPA 6. Jumlah peserta didik kelas XI IPA 5 sebanyak 27 orang dan XI IPA 6 sebanyak 25 orang dengan total 52 orang.

Data diperoleh dalam dua kali pertemuan, pertemuan pertama melihat aktivitas pembelajaran di kelas yang dilaksanakan pada tanggal 24 Februari 2017, dan pertemuan kedua pada pelaksanaan kegiatan praktikum di laboratorium tanggal 27 Februari 2017 untuk melihat kemunculan aspek keterampilan proses sains menggunakan lembar observasi. Data yang telah diperoleh selanjutnya dikelompokkan ke dalam tiga tingkatan, yaitu: (3) ada dan sesuai, (2) ada tetapi tidak sesuai, dan (1) belum ada. Tingkat kemunculan masing-masing indikator keterampilan proses sains peserta didik kelas XI IPA 5 dan IPA 6 dapat dilihat dalam Tabel 1.

\subsection{Analisis Data}

Analisis data dilakukan secara kuantitatif untuk menentukan kemunculan keterampilan proses sains peserta didik kelas XI IPA pada materi Larutan Penyangga.. Indikator keterampilan proses sains yang diobservasi meliputi keterampilan mengamati (observasi), menafsirkan (interpretasi), mengajukan pertanyaan, merumuskan hipotesis, menggunakan alat/bahan, menerapkan konsep, dan berkomunikasi. Untuk lebih jelasnya hasil observasi keterampilan proses sains peserta didik kelas XI IPA 5 dan IPA 6 akan dijelaskan dalam Tabel 1 berikut ini. 
Tabel 1. Hasil Observasi Keterampilan Proses Sains Kelas XI IPA 5 dan XI IPA 6 di SMAN 15 Padang

\begin{tabular}{|c|c|c|c|c|c|c|c|c|c|c|c|c|}
\hline \multirow{3}{*}{ No } & \multirow{3}{*}{$\begin{array}{c}\text { Indikator } \\
\text { Keterampilan } \\
\text { Proses Sains }\end{array}$} & \multirow{3}{*}{$\begin{array}{l}\text { Sub Indikator Keterampilan } \\
\text { Proses Sains yang Diamati }\end{array}$} & \multicolumn{9}{|c|}{ Tingkat Kemunculan } & \multirow{3}{*}{ Kategori } \\
\hline & & & \multicolumn{3}{|c|}{ Belum ada } & \multicolumn{3}{|c|}{$\begin{array}{l}\text { Ada tetapi tidak } \\
\text { sesuai }\end{array}$} & \multicolumn{3}{|c|}{ Ada dan sesuai } & \\
\hline & & & $\begin{array}{c}\text { XI } \\
\text { IPA } \\
5\end{array}$ & $\begin{array}{c}\text { XI } \\
\text { IPA } \\
6\end{array}$ & $\begin{array}{l}\text { Per } \\
\text { sen } \\
\text { tase }\end{array}$ & $\begin{array}{c}\text { XI } \\
\text { IPA } 5\end{array}$ & $\begin{array}{c}\text { XI } \\
\text { IPA } 6\end{array}$ & $\begin{array}{l}\text { Per } \\
\text { sen } \\
\text { tase }\end{array}$ & $\begin{array}{c}\text { XI } \\
\text { IPA } \\
\mathbf{5}\end{array}$ & $\begin{array}{c}\text { XI } \\
\text { IPA } \\
6\end{array}$ & $\begin{array}{l}\text { Per } \\
\text { sen } \\
\text { tase }\end{array}$ & \\
\hline 1 & Mengamati & $\begin{array}{l}\text { Mengamati perubahan indikator } \\
\text { universal dan menentukan nilai } \\
\text { pH dari masing-masing larutan } \\
\text { yang tersedia }\end{array}$ & 0 & 0 & $0 \%$ & 17 & 10 & $52 \%$ & 10 & 15 & $48 \%$ & $\begin{array}{l}\text { Ada tetapi } \\
\text { tidak sesuai }\end{array}$ \\
\hline \multirow{2}{*}{2} & \multirow{2}{*}{ Menafsirkan } & Menganalisis data & 5 & 1 & $11.5 \%$ & 14 & 12 & $50 \%$ & 8 & 12 & $38.5 \%$ & \multirow{2}{*}{$\begin{array}{l}\text { Ada tetapi } \\
\text { tidak sesuai }\end{array}$} \\
\hline & & Membuat kesimpulan & 11 & 4 & $28.8 \%$ & 7 & 17 & $46.2 \%$ & 9 & 4 & $25 \%$ & \\
\hline 3 & $\begin{array}{l}\text { Mengajukan } \\
\text { pertanyaan }\end{array}$ & $\begin{array}{l}\text { Bertanya untuk meminta } \\
\text { penjelasan }\end{array}$ & 21 & 20 & $78.8 \%$ & 0 & 0 & $0 \%$ & 6 & 5 & $21.2 \%$ & Belum ada \\
\hline 4 & $\begin{array}{l}\text { Merumuskan } \\
\text { Hipotesis }\end{array}$ & $\begin{array}{l}\text { Membuat hipotesis/ dugaan } \\
\text { sederhana }\end{array}$ & 8 & 2 & $19.2 \%$ & 2 & 1 & $5.8 \%$ & 17 & 22 & $75 \%$ & $\begin{array}{l}\text { Ada dan } \\
\text { sesuai }\end{array}$ \\
\hline 5 & $\begin{array}{l}\text { Menggunakan } \\
\text { alat/bahan }\end{array}$ & $\begin{array}{l}\text { Menggunakan alat/ bahan dengan } \\
\text { teknik yang benar }\end{array}$ & 0 & 0 & $0 \%$ & 13 & 12 & $48.1 \%$ & 14 & 13 & $51.9 \%$ & $\begin{array}{l}\text { Ada dan } \\
\text { sesuai }\end{array}$ \\
\hline 6 & $\begin{array}{l}\text { Menerapkan } \\
\text { konsep }\end{array}$ & Menghitung $\mathrm{pH}$ larutan penyangga & 6 & 1 & $13.5 \%$ & 21 & 24 & $86.5 \%$ & 0 & 0 & $0 \%$ & $\begin{array}{l}\text { Ada tetapi } \\
\text { tidak sesuai }\end{array}$ \\
\hline \multirow{2}{*}{7} & \multirow{2}{*}{ Berkomunikasi } & $\begin{array}{l}\text { Menanggapi/ menjawab } \\
\text { pertanyaan }\end{array}$ & 22 & 22 & $84.6 \%$ & 2 & 1 & $5.8 \%$ & 3 & 2 & $9.6 \%$ & \multirow{2}{*}{ Belum ada } \\
\hline & & $\begin{array}{l}\text { Menyajikan hasil dalam bentuk } \\
\text { laporan praktikum }\end{array}$ & 4 & 4 & $15.4 \%$ & 23 & 21 & $84.6 \%$ & 0 & 0 & $0 \%$ & \\
\hline
\end{tabular}


Berdasarkan Tabel 1 di atas, dapat diketahui bahwa dari 7 indikator KPS yang dilakukan penelitian, hanya ada 2 indikator yang berada pada kategori ada dan sesuai yaitu indikator merumuskan hipotesis dan menggunakan alat/bahan. Sedangkan indikator yang berada pada kategori ada tetapi tidak sesuai yaitu indikator mengamati, menafsirkan, dan menerapkan konsep. Selanjutnya indikator yang berada pada kategori belum ada yaitu indikator mengajukan pertanyaan dan berkomunikasi.

\section{Hasil dan Pembahasan}

Keterampilan proses sains menekankan pada pengembangan keterampilan-keterampilan tertentu dari peserta didik agar mampu menemukan dan mengembangkan suatu konsep dalam pembelajaran. Dalam penelitian ini ada 7 indikator keterampilan proses sains yang diukur tingkat kemunculannya.

Indikator yang pertama adalah keterampilan mengamati. Melakukan pengamatan merupakan penggunaan alat indera secara optimal dalam rangka memperoleh suatu informasi ${ }^{[7]}$. Hasil observasi yang didapatkan, untuk kategori ada dan sesuai memiliki persentase $48 \%$, ada tetapi tidak sesuai $52 \%$, dan belum ada $0 \%$. Untuk kategori ada dan sesuai memiliki persentase $48 \%$, artinya sebagian peserta didik sudah mampu menentukan nilai $\mathrm{pH}$ yang benar sesuai dengan teori, namun sebagian lagi masih belum. Ada 10 kelompok yang melakukan praktikum larutan penyangga, namun hanya 5 kelompok saja yang mendapatkan hasil yang sesuai dengan teori. Berdasarkan hasil pengamatan observer, kelompok-kelompok tersebut lebih teliti dan bersih dalam bekerja, sehingga hasil yang didapatkannya benar.

Kategori ada tetapi tidak sesuai memiliki persentase yang paling tinggi yaitu $52 \%$, artinya sebagian peserta didik banyak menuliskan nilai $\mathrm{pH}$ yang berbeda dengan yang seharusnya atau tidak sesuai dengan teori. Ada beberapa alasan yang menyebabkan peserta didik menuliskan nilai pH yang tidak sesuai dengan yang seharusnya, yaitu: kebersihan yang kurang dalam bekerja, alat-alat yang digunakan tidak dibilas dengan aquades sebelum menggunakan zat baru, dan kurang terampil dalam mencocokkan kertas indikator universal dengan trayek pH untuk menentukan nilai $\mathrm{pH}$ suatu larutan. Kategori belum ada memiliki persentase $0 \%$, artinya tidak ada peserta didik yang tidak melakukan pengamatan terhadap perubahan kertas indikator universal ketika dicelupkan ke dalam larutan-larutan yang ada untuk menentukan nilai $\mathrm{pH}$ dari larutan tersebut. Seluruh peserta didik melaksanakan praktikum dan mendapatkan giliran dalam menggunakan kertas indikator.

Indikator yang kedua adalah keterampilan menafsirkan. Dalam indikator menafsirkan ada dua sub indikator yang dilihat kemunculannya. Sub indikator yang pertama adalah keterampilan dalam menganalisis data dan sub indikator yang kedua adalah keterampilan membuat kesimpulan. Tujuan dari kegiatan ini untuk menginterpretasi hasil pengamatan atau pengukuran suatu objek yang telah dilakukan berdasarkan pada pola hasil pengamatan yang satu dengan yang lainnya ${ }^{[8]}$.

Hasil observasi untuk sub indikator keterampilan menganalisis data diperoleh hasil yaitu kategori ada dan sesuai $38.5 \%$, ada tetapi tidak sesuai $50 \%$, dan belum ada $11.5 \%$. Untuk kategori ada dan sesuai memiliki persentase yang lebih rendah dibandingkan kategori ada tetapi tidak sesuai, artinya jumlah peserta didik yang menjawab seluruh pertanyaan dengan benar lebih sedikit dibandingkan jumlah peserta didik yang menjawab dengan tidak lengkap. Kategori belum ada memiliki persentase $11.5 \%$, artinya masih ada beberapa peserta didik yang tidak menjawab pertanyaan yang ada dalam LKPD.

Sub indikator yang kedua adalah keterampilan membuat kesimpulan. Data ini didapatkan dari kesimpulan yang dibuat oleh masing-masing peserta didik yang tersedia dalam LKPD praktikum. Hasil observasi yang didapatkan, untuk kategori ada dan sesuai $25 \%$, ada tetapi tidak sesuai $46.2 \%$, dan belum ada $28.8 \%$. Kategori ada dan sesuai memiliki persentase $25 \%$, artinya sudah ada beberapa dari peserta didik yang mampu membuat kesimpulan sesuai dengan tujuan praktikum. Hal ini menunjukkan bahwa peserta didik sudah mampu memaknai percobaan yang telah dilakukannya, sehingga dapat mengambil suatu kesimpulan dari percobaan tersebut. Kategori ada tetapi tidak sesuai memiliki persentase tertinggi $46.2 \%$, dikarenakan kesimpulan yang dibuat peserta didik sebagian besar tidak sesuai dengan tujuan praktikum. Hal ini disebabkan karena peserta didik dalam membuat kesimpulan tidak merujuk ke tujuan praktikum yang dilaksanakan, dimana tujuan praktikum juga sudah dituliskan dalam LKPD. Kategori belum ada memiliki persentase $28.8 \%$, artinya masih ada beberapa peserta didik yang tidak membuat kesimpulan dalam LKPD-nya. 
Indikator yang ketiga adalah keterampilan mengajukan pertanyaan. Hasil observasi didapatkan, untuk kategori ada dan sesuai $21.2 \%$, ada tetapi tidak sesuai $0 \%$, dan belum ada $78.8 \%$. Kategori ada dan sesuai memiliki persentase $21.2 \%$, artinya sudah ada beberapa dari peserta didik yang mau mengajukan pertanyaan untuk meminta penjelasan mengenai konsep yang belum dipahami atau diragukan dan mengenai kegiatan praktikum yang dilaksanakan. Peserta didik yang mampu untuk bertanya berarti memiliki keberanian yang tinggi dan rasa ingin tahu yang besar untuk memperoleh ilmu pengetahuan yang semakin banyak. Kategori ada tetapi tidak sesuai memiliki persentase $0 \%$, artinya tidak ada peserta didik yang bertanya tidak sesuai dengan topik. Jika peserta didik bertanya tidak sesuai dengan topik, berarti pertanyaan tidak sejalan dengan apa yang sedang dipelajari dan dipraktikumkan. Kategori belum ada memiliki persentase tertinggi $78.8 \%$, artinya sebagian besar dari peserta didik tidak mau bertanya untuk meminta penjelasan, baik itu dalam proses pembelajaran di kelas maupun dalam kegiatan praktikum di laboratorium.

Indikator yang keempat adalah keterampilan merumuskan hipotesis. Hasil observasi yang didapatkan, untuk kategori ada dan sesuai $75 \%$, ada tetapi tidak sesuai $5.8 \%$, dan belum ada $19.2 \%$. Kategori ada dan sesuai memiliki persentase yang paling tinggi $75 \%$, artinya sebagian besar peserta didik sudah menjawab pertanyaan hipotesis dengan benar. Kebenaran hipotesis yang dibuat peserta didik disebabkan karena mereka telah mempelajari konsep larutan penyangga sebelumnya, sehingga pada saat praktikum sebagian besar peserta didik sudah mempunyai konsep awal dan mampu menjawab pertanyaan hipotesis yang diberikan. Kategori ada tetapi tidak sesuai memiliki persentase $5.8 \%$, artinya beberapa peserta didik ada yang membuat hipotesis dengan tidak benar dan tidak lengkap. Kategori belum ada memiliki persentase $19.2 \%$, artinya sebagian kecil peserta didik tidak menjawab pertanyaan hipotesis yang diberikan.

Indikator yang kelima adalah keterampilan menggunakan alat/bahan. Hasil observasi yang didapatkan yaitu untuk kategori ada dan sesuai 51.9\%, ada tetapi tidak sesuai $48.1 \%$, dan belum ada $0 \%$. Kategori ada dan sesuai memiliki persentase yang paling tinggi yaitu $51.9 \%$, artinya sebagian besar dari peserta didik sudah mampu menggunakan pipet tetes dengan teknik yang benar. Untuk kategori ada tetapi tidak sesuai memiliki persentase $48.1 \%$, artinya sebagian peserta didik belum mampu menggunakan pipet tetes dengan teknik yang benar. Mereka masih ragu-ragu dalam menggunakannya, sehingga ada tekniknya yang terbalik dalam memencet bagian atas dari pipet tetes tersebut. Untuk kategori belum ada memiliki persentase $0 \%$, artinya semua peserta didik melaksanakan praktikum dan semuanya mendapatkan giliran menggunakan pipet tetes dalam mengambil larutan.

Indikator yang keenam adalah keterampilan menerapkan konsep. Hasil observasi yang didapatkan, untuk kategori ada dan sesuai 0\%, ada tetapi tidak sesuai 86.5\%, dan belum ada $13.5 \%$. Kategori ada dan sesuai memiliki persentase $0 \%$, artinya tidak ada dari peserta didik yang mampu menjawab pertanyaan LKPD No.6-7 dengan benar dan lengkap. Hal ini disebabkan karena peserta didik belum mampu memahami penjabaran rumus dalam mencari $\mathrm{pH}$ larutan penyangga asam ataupun penyangga basa, sehingga mereka kesulitan dalam menjawab pertanyaan-pertanyaan yang diberikan. Selain itu, pemahaman mengenai materi prasyarat seperti Teori Asam Basa Bronsted Lowry dan Kesetimbangan Larutan Asam Basa juga masih belum paham.

Kategori ada tetapi tidak sesuai memiliki persentase tertinggi yaitu $86.5 \%$, artinya sebagian besar peserta didik belum mampu menjawab pertanyaan-pertanyaan tersebut dengan benar. Hal ini disebabkan karena mereka banyak menggunakan rumus yang salah, meskipun sudah diberikan rumus di dalam LKPD praktikum dan juga sudah dijabarkan beberapa rumus oleh guru dalam pembelajaran di kelas. Namun, mereka masih menjawab dengan jawaban yang tidak benar. Sehingga dapat disimpulkan sebagian besar dari peserta didik belum memahami penjabaran rumus dalam menghitung nilai $\mathrm{pH}$ larutan penyangga asam/basa. Kategori belum ada memiliki persentase $13.5 \%$, artinya masih ada beberapa peserta didik yang tidak mengerjakan pertanyaan LKPD No.6-7.

Indikator yang ketujuh adalah keterampilan berkomunikasi. Ada dua sub indikator yang diukur yaitu keterampilan menanggapi/menjawab pertanyaan dan menyajikan hasil dalam bentuk laporan secara sistematis. Sub indikator menanggapi/menjawab pertanyaan dilihat dari kemampuan peserta didik dalam menanggapi/menjawab pertanyaan yang diberikan guru atau teman-temannya. Hasil observasi didapatkan yaitu untuk kategori ada dan sesuai $9.6 \%$, ada tetapi tidak sesuai 5.8\%, dan belum ada $84.6 \%$.

Kategori ada dan sesuai memiliki persentase $9.6 \%$, artinya hanya ada beberapa peserta didik yang mau untuk menanggapi/menjawab pertanyaan yang diberikan guru atau teman-temannya. 
Mereka yang mau menanggapi/ menjawab pertanyaan adalah mereka yang sudah memiliki sedikit pemahaman mengenai materi Larutan Penyangga, dan yang memiliki keberanian untuk menyampaikan gagasannya. Kategori ada tetapi tidak sesuai memiliki persentase $5.8 \%$, artinya ada beberapa dari peserta didik yang menanggapi/ menjawab pertanyaan dengan jawaban yang tidak benar. Namun, keberanian dari peserta didik tersebut harus dihargai meskipun jawaban/gagasan yang diungkapkannya salah, setidaknya mereka sudah mau mencoba. Kategori belum ada memiliki nilai persentase tertinggi yaitu $84.6 \%$, artinya sebagian besar peserta didik belum mampu mengungkapkan gagasan atau menjawab pertanyaan yang diberikan oleh guru atau teman-temannya secara langsung di depan kelas, masih ada rasa malu ataupun rasa tidak percaya diri karena pemahaman yang masih sedikit untuk menyampaikan gagasan atau jawaban di depan teman-temannya.

Sub indikator yang kedua adalah menyajikan hasil dalam bentuk laporan. Laporan dibuat oleh masing-masing peserta didik berdasarkan data yang didapatkan pada saat pelaksanaan kegiatan praktikum dan dihubungkan dengan teori yang benar. Hasil observasi yang didapatkan yaitu untuk kategori ada dan sesuai $0 \%$, ada tetapi tidak sesuai $84.6 \%$, dan belum ada $15.4 \%$.

Kategori ada dan sesuai memiliki persentase $0 \%$, artinya belum ada dari peserta didik yang mampu membuat laporan secara sistematis berdasarkan hasil percobaan dan menghubungkan dengan teori yang benar. Kategori ada tetapi tidak sesuai memiliki persentase tertinggi yaitu $84.6 \%$, artinya sebagian besar peserta didik menyusun laporan dengan tidak sistematis, seperti bagian pembahasan dan daftar kepustakaan ada yang tidak dibuatkan, padahal bagian tersebut merupakan bagian yang penting dalam suatu laporan praktikum. Selain itu, peserta didik banyak yang tidak menghubungkan hasil pengamatan dengan teori yang sebenarnya, hal ini dapat dilihat dari pembahasan yang tidak dijelaskan secara rinci, hanya sedikit saja. Kategori belum ada memiliki persentase $15.4 \%$, artinya beberapa peserta didik tidak membuat laporan praktikum.

Penerapan keterampilan proses sains dalam pembelajaran merupakan hal yang harus dilaksanakan oleh guru dalam pembelajaran. Peserta didik akan mudah memahami konsep-konsep jika disertai dengan situasi dan kondisi yang dihadapi, dengan mempraktekkan sendiri upaya penemuan konsep melalui perlakuan terhadap kenyataan fisik. Pendekatan keterampilan proses sains bertolak dari suatu pandangan bahwa setiap anak memiliki potensi yang berbeda-beda. Oleh karena itu, setiap guru harus mampu menciptakan situasi dan kondisi belajar yang dapat mengembangkan kemampuan peserta didik secara optimal.

\section{KESIMPULAN}

Berdasarkan hasil penelitian, keterampilan proses sains peserta didik kelas XI IPA di SMAN 15 Padang belum berkembang secara optimal. Indikator KPS yang berada pada kategori ada dan sesuai yaitu keterampilan mengklasifikasi, merumuskan hipotesis, dan menggunakan alat/bahan. Indikator KPS yang berada pada kategori ada tetapi tidak sesuai yaitu keterampilan mengamati, menafsirkan, dan menerapkan konsep. Selanjutnya indikator KPS yang berada pada kategori belum ada yaitu keterampilan mengajukan pertanyaan dan berkomunikasi.

\section{REFERENSI}

[1] Mulyasa. 2011. Menjadi Guru Profeional Menciptakan Pembelajaran Kreatif dan Menyenangkan. Bandung: PT. Remaja Rosdakarya.

[2] Permendikbud RI No.59. 2014. Kurikulum 2013 Sekolah Menengah Atas/Madrasah Aliyah. Jakarta: Depdiknas.

[3] Sagala, Syaiful. 2003. Konsep dan Makna Pembelajaran. Bandung: Alfabeta.

[4] Arifin, Zainal. 2012. Penelitian Pendidikan. Bandung: PT. Remaja Rosdakarya.

[5] Arikunto, Suharsimi. 2010. Prosedur Penelitian Suatu Pendekatan Praktik (Edisi Revisi 2010). Jakarta: Rineka Cipta.

[6] Sugiyono. 2013. Metode Penelitian Kombinasi (Mixed Methods). Bandung: Alfabeta.

[7] Suryosubroto. 2009. Proses Belajar Mengajar di Sekolah. Jakarta: Rineka Cipta. 
[8] Tawil,Muh \& Liliasari. 2014. Keterampilan-keterampilan Sains dan Implementasinya dalam Pembelajaran IPA. Makassar: Badan Penerbit Universitas Negeri Makassar.

[9] Putri, G. A., H., \& Zainul, R. (2017, August 24). Development of Periodic Table Interactive Instructional Multimedia in Chemistry Lesson For Xth Grade SMA/MA. https://doi.org/10.31227/osf.io/2hsme

[10] Murni, H. P., Dj, L., \& Zainul, R. (2017, January 2). Pengembangan Penuntun Praktikum Kimia Berorientasi Chemoentrepreneurship untuk SMA/MA Kelas XII Semester Ganjil. https://doi.org/10.31227/osf.io/m23ac

[11] Zainul, R. (2016, February 19). Disain, Metode dan Penggunaan Software Pembelajaran Kimia Berbasis IT untuk Aktivitas Kelas dan Laboratorium Berbasis Inkuiri Terbimbing. https://doi.org/10.31227/osf.io/psf5t

[12] Sepriandi, P., E., \& Zainul, R. (2016, August 15). Pengembangan LKS Dengan Pendekatan Saintifik Berbasis Discovery Learning pada Materi Asam Basa untuk Pembelajaran Kimia Kelas XI SMA/MA. https://doi.org/10.31227/osf.io/5cb3h

[13] Handayani, D. P., Zainul, R., \& Azra, F. (2018, February 1). Pengembangan Multimedia Prezi Berbasis Problem Based Learning (PBL) pada Materi Hukum-Hukum Dasar Kimia Kelas X IPA di SMAN 1 Bukittinggi. https://doi.org/10.31227/osf.io/yqpem

[14] Lusi, D. F., Y., \& Zainul, R. (2018, May 7). Efektivitas Modul Larutan Elektrolit dan Nonelektrolit Berbasis Discovery Learning Terhadap Keterampilan Berpikir Kritis dan Hasil Belajar Siswa Kelas $X \quad$ MIPA SMAN 2 Bukittinggi. https://doi.org/10.31227/osf.io/b2vtx

[15] Maypalita, F., M., \& Zainul, R. (2017, August 16). Pengaruh Penggunaan Lembar Kerja Siswa (LKS) Berbasis Inkuiri Terbimbing pada Materi Larutan Penyangga terhadap Hasil Belajar Siswa Kelas XI IPA SMAN 5 Padang. https://doi.org/10.31227/osf.io/j3fxc

[16] Jannah, A. R., Afkar, Z., \& Zainul, R. (2017, February 6). Pengembangan Media Pembelajaran Asam Basa Menggunakan Aplikasi Android Berbasis Chemistry Triangle Kelas XI SMA/MA. https://doi.org/10.31227/osf.io/muh8y 